\title{
Kajian Kekuatan Tanah dan Kestabilan Tubuh Tanggul Pada Rencana Tanggul Wedok Lumpur Sidoarjo, Kecamatan Porong, Kabupaten Sidoarjo, Provinsi Jawa Timur
}

\author{
Devina Trisnawati ${ }^{1 *}$, Suhesti $^{1}$, Wahju Krisna Hidajat ${ }^{1}$ \\ ${ }^{1}$ Teknik Geologi, Fakultas Teknik, Universitas Diponegoro, Semarang, Indonesia
}

\begin{abstract}
Abstrak
Semburan lumpur Sidoarjo di Porong belum berhenti hingga saat ini, sehingga tahun 2019 Pusat Pengendalian Lumpur Sidoarjo (PPLS) berencana membangun tanggul baru di sisi timur tanggul utama setinggi $5 \mathrm{~m}$ yakni tanggul Wedok. Dalam pembangunan tanggul Wedok perlu diketahui kekuatan tanah dasar serta stabilitas tubuh tanggul. Untuk itu, dilakukan kajian mengenai kekuatan tanah penopang tanggul dan kestabilan tubuh tanggul mengunakan metode finite element dengan perangkat lunak Phase2 V8.0. Berdasarkan data pemetaan geologi lokasi penelitian tersusun oleh litologi endapan aluvial dan endapan lumpur Sidoarjo, sedangkan berdasarkan penyelidikan geologi teknik terbagi menjadi tiga satuan, yakni : satuan tanah urugan, satuan endapan lumpur Sidoarjo, dan satuan tanah asli. Tanah dasar pada lokasi rencana tanggul berupa lempung lunak yang tebal dengan kemampuan menahan beban tanggul setinggi $2,15 \mathrm{~m}$. Pemasangan PVD (Prevabricated Vertical Drain) pada tanah dasar meningkatkan nilai faktor keamanan (FK) pada stabilitas tubuh tanggul.
\end{abstract}

Kata kunci: Tanggul Wedok; kestabilan lereng; finite element; tanah dasar; PVD.

\begin{abstract}
The Sidoarjo mudflow in Porong has not stopped until now, therefore in 2019 the Pusat Pengendalian Lumpur Sidoarjo (PPLS) plans to build a new embankment on the east side of the main embankment as high as $5 \mathrm{~m}$, namely the Wedok embankment. In the consruction of Wedok embankment it is necessary to know the strength of the subgrade and the stability of the embankment body. For this reason, a study was conducted on the strength of the embankment supporting soil and the stability of the embankment body using the finite element method with Phase 2 V.0 software. Based on geological mapping data, the research site is composed of lithology alluvial sediment and Sidoarjo mud deposit, while based on technical geological investigation is divided into three units, namely: subgrade soil unit, Sidoarjo mud deposit unit, and original soil unit. The subgrade at the dike plan location is thick soft clay with the ability to withstand embankment loads as high as $2.15 \mathrm{~m}$. Installation of PVD (Prevabricated Vertical Drain) on subgrade increases the value of safety factor (FK) on the stability of the embankment body.
\end{abstract}

Keyword: Wedok embankment; slope stability; finite element; subgrade; PVD.

\section{PENDAHULUAN}

Semburan lumpur Sidoarjo hingga saat ini terus aktif sehingga Pusat Pengendalian Lumpur Sidoarjo (PPLS) berencana membangun Tanggul Wedok di sisi timur tanggul utama guna mengantisipasi luapan lumpur agar tidak meluas di daerah sekitar. Menurut Widodo dan Hariyanto (2016) lumpur Sidoarjo diklasifikasikan menjadi empat kelas yaitu air berlumpur, lumpur basah, lumpur kering, dan lumpur mulai mengering. Lumpur basah memiliki potensi yang besar untuk merusak tanggul. Persebaran lumpur basah berada di sebelah timur area semburan lumpur Sidoarjo. Tanggul Wedok akan dibangun di atas tanah dasar berupa tanah lunak sehingga dalam pembangunannya diperlukan perbaikan tanah (Badan Penanggulangan Lumpur Sidoarjo, 2016).

Kondisi ini memiliki kemiripan dengan bendungan Marangkayu di Kalimantan Timur. Pengaplikasian rekayasa geoteknik berupa pemasangan Prevabricated Vertical Drain (PVD) pada tanah dasar di bendungan Marangkayu terbukti mampu membantu meningkatkan nilai faktor keamanan (FK) pada tubuh bendungan (Raden dkk., 2016).

Tanggul Wedok secara prinsip memiliki instrumentasi yang sama dengan bendungan tipe urugan. Tipe instrumentasi bendungan urugan 
serbasama yang digunakan dalam pembuatan tanggul wedok. Tipe instrumentasi ini menggunakan material timbunan yang seragam (Badan Standarisasi Nasional, 2004). Material timbunan dipilih dari 2 jenis material yakni : berasal dari borrow area dan material campuran (70\% borrow area dan $30 \%$ endapan lumpur Sidoarjo).

Berdasarkan uraian di atas, maka diperlukan kajian mengenai kekuatan tanah dasar dan kestabilan tubuh tanggul. Pada penelitian ini akan dilakukan pengaplikasian rekayasa geoteknik berupa PVD dalam analisis (FK).

\section{Tanah Dasar}

Tanah dasar merupakan permukaan tanah asli atau tanah timbunan yang dipadatkan untuk perencanaan bangunan. Pada pekerjaan keteknikan tanah merupakan objek vital karena menjadi landasan dalam meletakkan konstruksi. Untuk itu, diperlukan kondisi tanah yang stabil untuk mendukung pembangunan tanggul. Schmertmann (1978) menghubungkan antara tekanan konus (qc), friction ratio (FR) dan jenis tanah berdasarkan uji sondir pada Gambar 1 .

\section{Daya Dukung Tanah Dasar}

Dalam pembangunan suatu konstruksi perlu memperhatikan kekuatan tanah memikul beban konstruksi. Kemampuan tanah untuk memikul beban maksimum yang diijinkan disebut daya dukung tanah. Secara kuantitatif daya dukung tanah dapat dihitung dari persamaan 1 dan 2 .

$$
\text { qall }=\frac{Q u l t}{S F}
$$

Keterangan : qall = tegangan tanah yang diizinkan

$$
\text { Qult = daya dukung batas }
$$$$
\mathrm{SF}=\text { faktor keamanan (tanggul 2) }
$$

$$
\gamma \times \mathrm{h}=\frac{c \times N c}{S F}
$$

Keterangan : $\gamma=$ berat jenis $\left(\mathrm{kN} / \mathrm{m}^{3}\right)$

$\mathrm{h}=$ ketinggian material yang diizinkan

$\mathrm{c}=$ kohesi $\left(\mathrm{kN} / \mathrm{m}^{2}\right)$

$\mathrm{Nc}=$ faktor-faktor daya dukung tanah (lempung 5,14)

\section{Stabilitas Tubuh Tanggul}

Analisis kestabilan tubuh tanggul penting dilakukan untuk meminimalisir terjadinya kegagalan tanggul. Secara umum tujuan dari stabilitas tanggul adalah untuk memperkirakan bentuk keruntuhan dan menentukan tingkat kera-

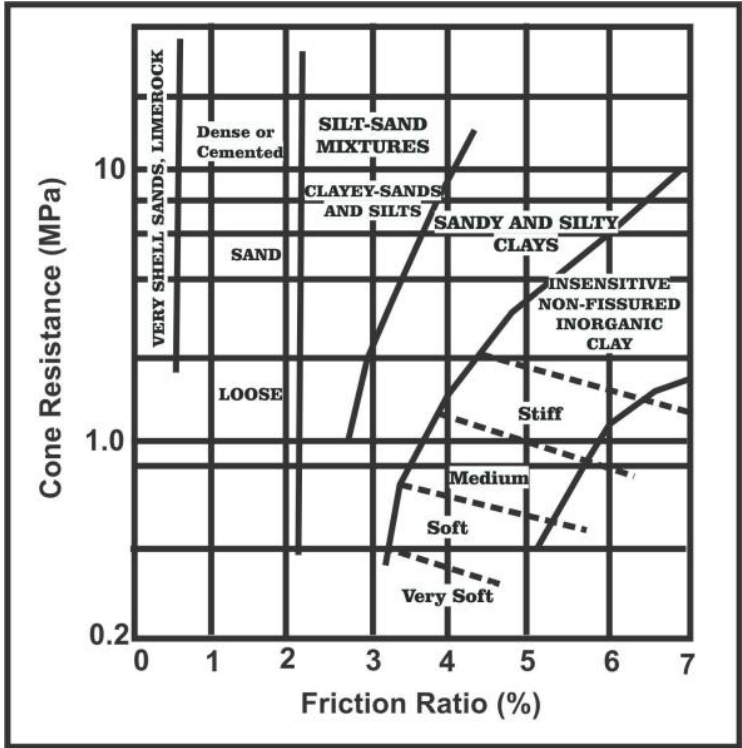

Gambar 1. Sistem klasifikasi tanah berdasarkan usulan Schmertmann (1978).

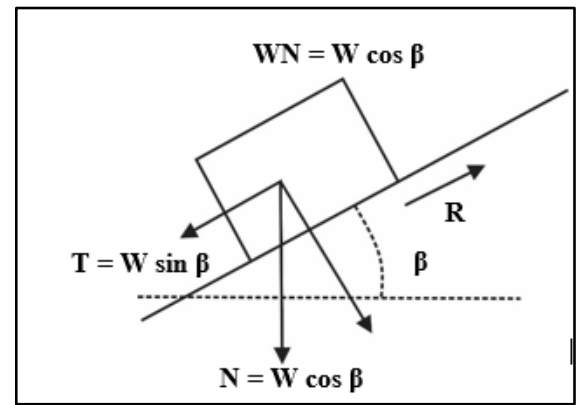

Gambar 2. Simulasi komponen gaya pada lereng (Sukandi, 2011).

wanan tanggul terhadap longsoran serta merancang suatu tanggul timbunan agar memenuhi kriteria keamanannya (Sukandi, 2011). Gaya yang tegak lurus atau normal terhadap bidang miring cenderung mempertahankan kondisi kesetimbangan blok massa. Simulasi komponen gaya yang bekerja pada stabilitas lereng dapat dilihat pada Gambar 2.

Nilai syarat faktor keamanan minimum dalam analisis kestabilan lereng berdasarkan Badan Standarisasi Nasional (2016) dapat dilihat pada Tabel 1.

\section{METODOLOGI}

Dalam kajian kekuatan tanah dasar dan penentuan kesatabilan tubuh tanggul diperlukan data meliputi : jenis litologi, sifat fisik dan mekanik tanah dasar dan timbunan. Data diperoleh dengan metode pemetaan permukaan dan bawah permukaan. Pemetaan bawah permukaan dilakukan dengan cara penyelidikan geoteknik. 
Selanjutnya analisis kestabilan tanggul dilakukan dengan bantuan program Phase2 V8.0 berbasis elemen hingga.

Metode elemen hingga merupakan metode numerik yang digunakan untuk memecahkan permasalahan keteknikan yang berkaitan dengan analisis struktur, perpindahan panas, aliran fluida, perpindahan masa dan potensial elektromagnetik. Dalam metode elemen hingga, domain dari daerah yang dianalisis dibagi menjadi sejumlah zonazona yang lebih kecil. Zona-zona kecil tersebut dinamakan elemen. Elemen-elemen tersebut dianggap saling berkaitan satu sama lain pada sejumlah titik-titik simpul. Perpindahan pada setiap titik-titik simpul dihitung terlebih dahulu, kemudian dengan sejumlah fungsi interpolasi yang diasumsikan, perpindahan pada sembarang titik dapat dihitung berdasarkan nilai perpindahan pada titik-titik simpul. Selanjutnya regangan yang terjadi pada setiap elemen dihitung berdasarkan besarnya perpindahan pada masing-masing titik simpul. Berdasarkan nilai regangan tersebut dapat dihitung tegangan yang bekerja pada setiap elemen (Ambarini dkk, 2014).

Metode elemen hingga dapat diasumsikan dengan fungsi linear pada sumbu $\mathrm{X}$ dan sumbu $\mathrm{Y}$ (Mulyadi, 2011). Fungsi linear pada sumbu $X$ dan $\mathrm{Y}$ dimasukkan ke dalam matriks kemudian dimasukkan ke dalam invers koordinat matriks sesuai persamaan 2.1.

$$
\begin{aligned}
& {\left[A_{\mathbf{1}}\right]^{-\mathbf{1}}=\left[\begin{array}{ccc}
1 & X_{\mathbf{1}} & Y_{\mathbf{1}} \\
1 & X_{\mathbf{2}} & Y_{\mathbf{2}} \\
1 & X_{\mathbf{3}} & Y_{\mathbf{3}}
\end{array}\right]^{-1}=\frac{\text { titik dari }\left[A_{\mathbf{1}}\right]}{\text { determinan }\left[A_{\mathbf{1}}\right]}} \\
& =\frac{\operatorname{det}\left[\begin{array}{ccc}
a_{1} & a_{2} & a_{3} \\
b_{1} & b_{3} & b_{3} \\
c_{1} & \operatorname{det} & c_{3}
\end{array}\right]}{\text { Keterangan }} \\
& \mathrm{a}_{1}=\mathrm{X}_{2} \mathrm{Y}_{2}-\mathrm{X}_{2} \mathrm{Y}_{2} \\
& \mathrm{a}_{2}=\mathrm{X}_{2} \mathrm{Y}_{1}-\mathrm{X}_{1} \mathrm{Y}_{2} \\
& a_{3}=X_{1} Y_{2}-X_{2} Y \\
& \text { det }=X_{2} Y_{2}-X_{2} Y_{2}+X_{1}\left(Y_{2}-Y_{2}\right)+Y_{1}\left(X_{2}-X_{2}\right)=2 \text { (area } \\
& \text { segitiga elemen) }
\end{aligned}
$$

Tabel 1. Persyaratan faktor keamanan bendungan tipe urugan (Badan Standarisasi Nasional, 2016).

\begin{tabular}{lccc}
\hline \multicolumn{1}{c}{ Kondisi } \\
Tanggul & $\begin{array}{r}\text { Tanpa } \\
\text { Beban } \\
\text { Gempa }\end{array}$ & $\begin{array}{c}\text { Syarat FK } \\
\text { Beban } \\
\text { Gempa } \\
\text { OBE }\end{array}$ & $\begin{array}{c}\text { Beban } \\
\text { Gempa } \\
\text { MDE }\end{array}$ \\
\hline Kosong & 1,3 & 1,2 & 1,0 \\
Banjir & 1,3 & 1,2 & 1,0 \\
Surut tiba-tiba & 1,3 & 1,1 & 1,0 \\
\hline
\end{tabular}

\section{HASIL PENELITIAN}

Secara umum daerah penelitian memiliki relief landai berkisar antara $5 \mathrm{~m}-12 \mathrm{~m}$ dengan bentuklahan antropogenik (Gambar 4).

\section{Kondisi Geologi Teknik}

Berdasarkan pemetaan geologi lokasi penelitian tersusun oleh dua satuan litologi yaitu satuan endapan lumpur Sidoarjo dan satuan alluvial. Kedua satuan tersebut dibedakan kembali berdasarkan sifat keteknikannya menjadi tiga satuan litologi yaitu satuan tanah urugan, satuan lumpur Sidoarjo, dan satuan tanah asli (Gambar $5)$.

Hasil pengujian bawah permukaan diperoleh hasil yang hampir sama antara pengujian sondir-1, sondir-2, dan hasil pemboran. Profil penampang bawah permukaan tanah ini terdapat lapisan pasir yang melensa. Semakin ke arah timur, lapisan pasir semakin menipis dan diinterpretasikan menghilang. Hal ini karena pada sondir dua tidak terdapat fraksi kasar seperti terlihat pada Gambar 6.

\section{Pengujian Laboratorium}

Pengujian laboratorium sifat fisik dan mekanika tanah pada percontoan tanah dasar pada titik DB-1 diperoleh hasil seperti terlihat pada Tabel 2 dan Tabel 3.

Tabel 2. Sifat fisik tanah

\begin{tabular}{lllllll}
\hline $\begin{array}{l}\text { Kedalaman } \\
(\mathrm{m})\end{array}$ & $\begin{array}{l}\mathrm{Wc} \\
(\%)\end{array}$ & Gs & $\begin{array}{l}\Gamma \mathrm{t} \\
\left(\mathrm{t} / \mathrm{m}^{3}\right)\end{array}$ & LL & PL & IP \\
\hline $02,00-02,50$ & 70 & 2,57 & 1,47 & 63 & 38 & 25 \\
$08,00-08,50$ & 118 & 2,57 & 1,38 & 56 & 30 & 26 \\
$12,00-12,50$ & 129 & 2,50 & 1,35 & 56 & 28 & 28 \\
$18,00-18,50$ & 121 & 2,51 & 1,37 & 67 & 34 & 33 \\
$22,00-22,50$ & 151 & 2,52 & 1,39 & 75 & 43 & 32 \\
$28,00-28,50$ & 101 & 2,50 & 1,42 & 79 & 41 & 38 \\
\hline
\end{tabular}

Tabel 3. Sifat mekanik tanah (Balai Litbang Sungai, 2018).

\begin{tabular}{llllll}
\hline $\begin{array}{l}\text { Kedalaman } \\
(\mathrm{m})\end{array}$ & \multicolumn{2}{l|}{ Strength } & \multicolumn{3}{l}{ Compressibility } \\
& & & & & \\
\hline & $\mathrm{C}$ & $\phi$ & $\Lambda$ & $\mathrm{Cv}$ & $\mathrm{OCR}$ \\
\hline & $\mathrm{Kg} /$ & $\left(^{\circ}\right)$ & & & \\
\hline $02,00-02,50$ & 0,15 & - & 0,300 & 0,041 & 3,75 \\
$08,00-08,50$ & 0,13 & - & 0,359 & 0,025 & 1,35 \\
$12,00-12,50$ & 0,11 & - & 0,353 & 0,023 & 1,77 \\
$18,00-18,50$ & 0,17 & - & 0,344 & 0,028 & 1,00 \\
$22,00-22,50$ & 0,18 & - & 0,349 & 0,032 & 0,86 \\
$28,00-28,50$ & 0,13 & - & 0,292 & 0,013 & 1,00 \\
\hline
\end{tabular}




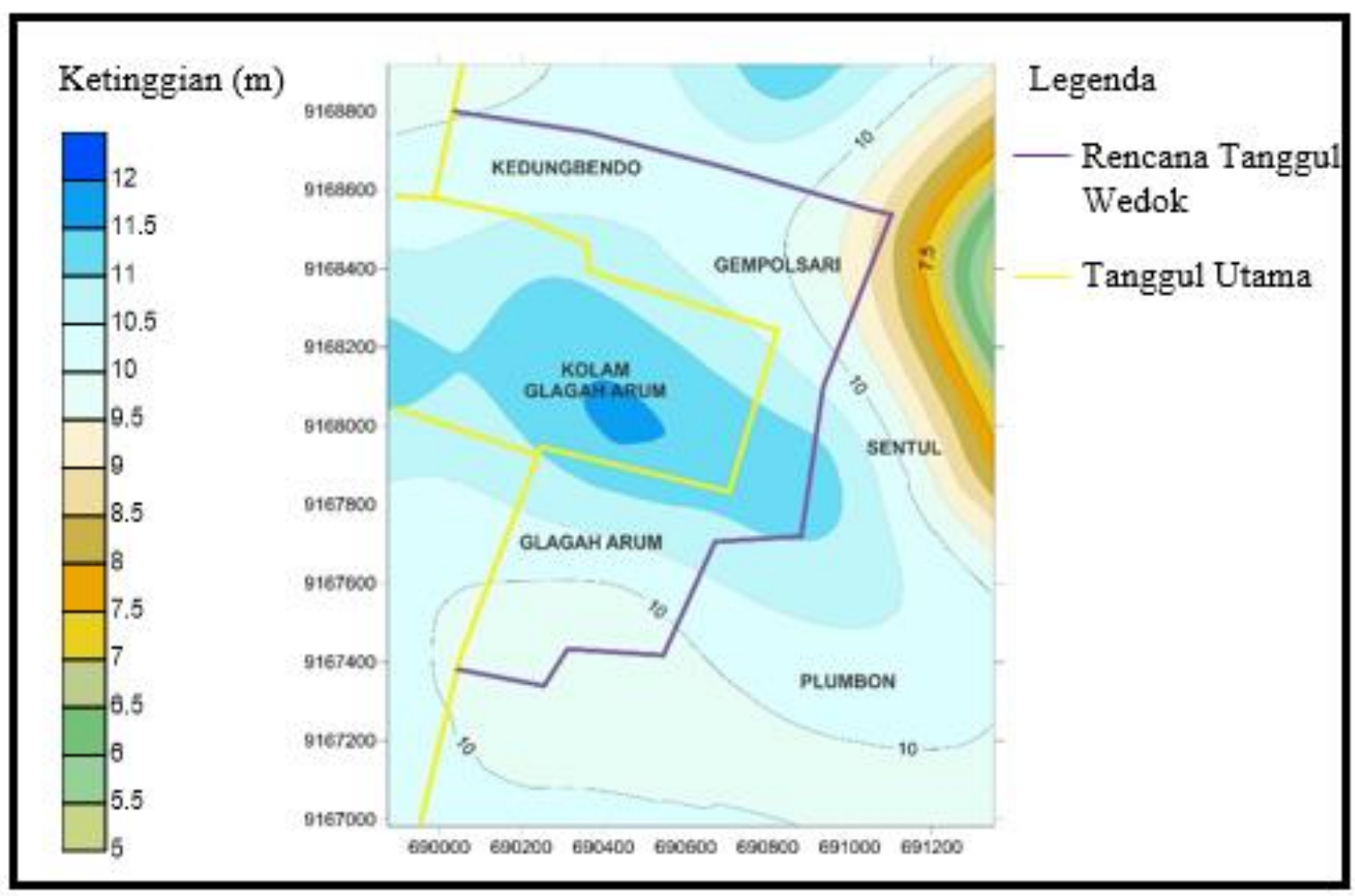

Gambar 4. Relief lokasi penelitian.

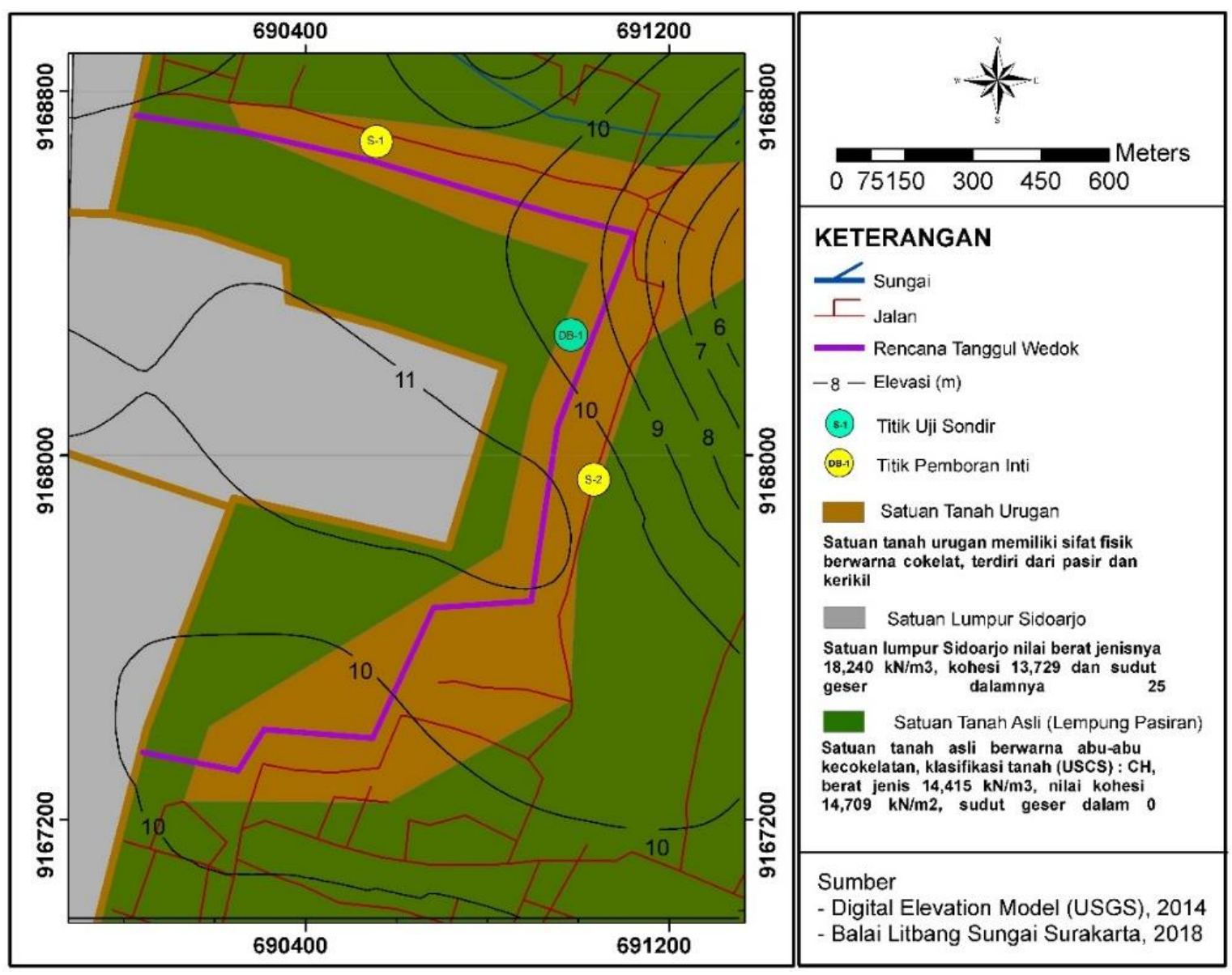

Gambar 5. Peta geologi teknik daerah penelitan. 


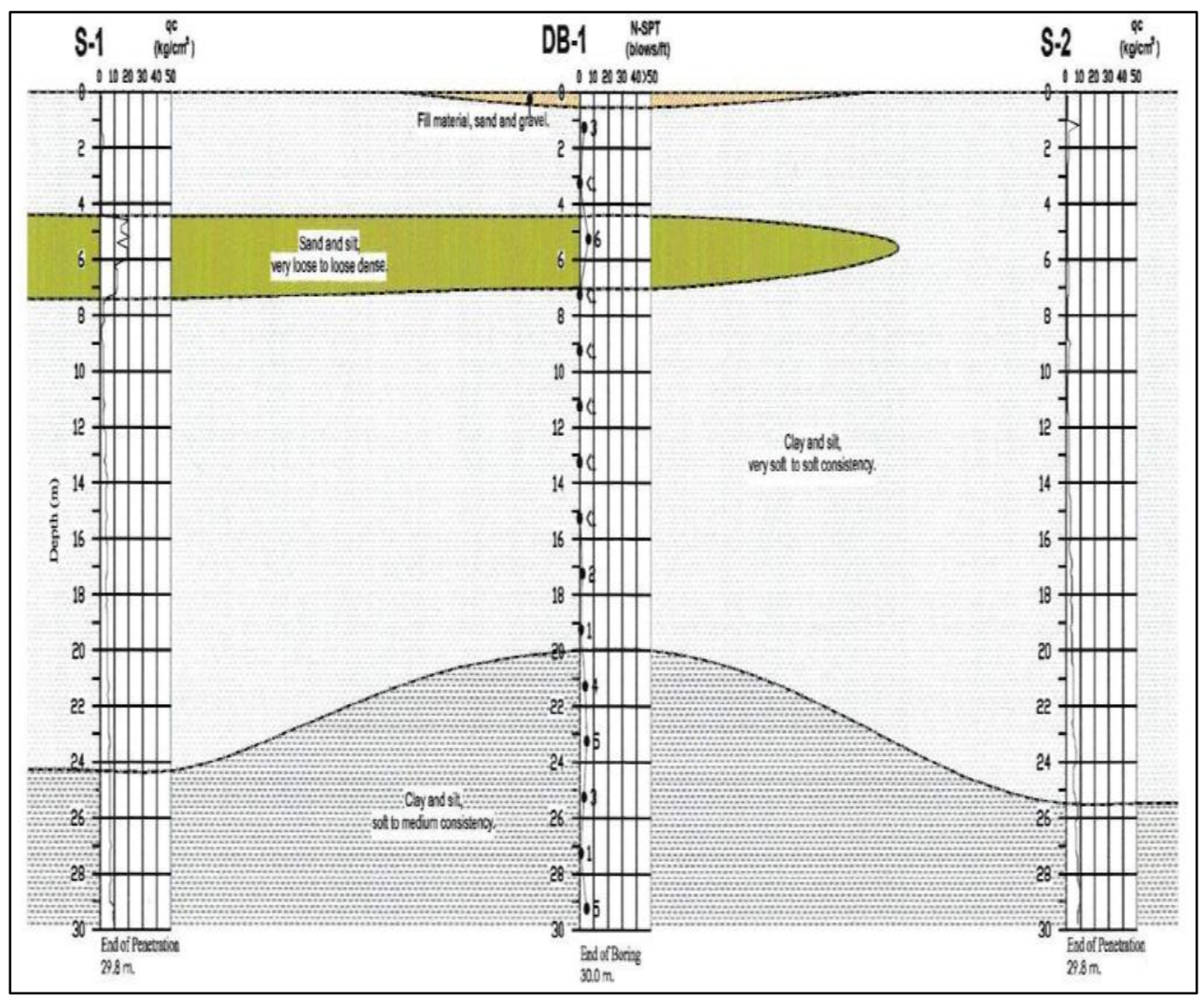

Gambar 6. Penampang bawah permukaan (Balai Litbang Sungai, 2018)

\section{Karakteristik Tanah Dasar}

Ketebalan lapisan tanah dasar berdasarkan daya dukung tanah yang diijinkan dihitung sebagai berikut

$$
\begin{array}{ll}
\text { qall }=\frac{\text { Qult }}{S F} & \mathrm{SF} \approx 2 \\
\gamma \times \mathrm{h}=\frac{c \times N c}{S F} & \mathrm{Nc} \approx 5,14 ; \text { untuk tanah lempung }
\end{array}
$$

(Terzaghi, 1943)

$$
\begin{aligned}
& 1,8 \times \mathrm{h}=\frac{1,5 \times 5,14}{2} \\
& 1,8 \times \mathrm{h}=3,855 \\
& \mathrm{~h}=2,1416 \\
& \mathrm{~h}=2,15 \mathrm{~m}
\end{aligned}
$$

\section{Faktor Gempa}

Berikut perhitungan kelas resiko gempa dengan menghitung pembobotan faktor kapasitas tanggul, tinggi tanggul, kebutuhan evakuasi, dan tingkat kerusakan hilir (BSN, 2004).

1. Kapasitas tanggul $\left(\mathrm{FR}_{\mathrm{k}}\right)$

2. Tinggi tanggul $\left(\mathrm{FR}_{\mathrm{t}}\right)$

$=3,52$ juta $\mathrm{m}^{3}$

3. Kebutuhan evakuasi $\left(\mathrm{FR}_{\mathrm{e}}\right) \quad=>1000$ jiwa

4. Tingkat kerusakan hilir $\left(\mathrm{FR}_{\mathrm{h}}\right)=$ sangat tinggi
Berdasarkan perhitungan kelas risiko gempa pada daerah rencana tanggul Wedok, perhitungan faktor resiko total sebagai berikut:

FRtot $=\mathrm{FR}_{\mathrm{k}}+\mathrm{FR}_{\mathrm{t}}+\mathrm{FR}_{\mathrm{e}}+\mathrm{FR}_{\mathrm{h}}$

$$
=4+0+12+12
$$$$
=28 \text { (III, tinggi) }
$$

Modifikasi perhitungan koefisien gempa lokasi penelitian seperti berikut ini :

a. Perhitungan dengan Gempa $\mathrm{OBE}_{50}$

$$
\begin{aligned}
\mathrm{K}_{\mathrm{h}} & =\mathrm{K}_{\mathrm{o}} \mathrm{x}(2,0-0,6 \times(\mathrm{Y} / \mathrm{H})) \\
& =0,076 \times(2,0-0,6 \times(5 / 5)) \\
& =0,106
\end{aligned}
$$

b. Perhitungan dengan Gempa $\mathrm{MDE}_{5.000}$

$$
\begin{aligned}
\mathrm{Kh} & =\operatorname{Ko} \times(2,0-0,6 \times(\mathrm{Y} / \mathrm{H})) \\
& =0,231 \times(2,0-0,6 \times(5 / 5)) \\
& =0,323
\end{aligned}
$$

Nilai koefisien gempa vertikal merupakan setengah dari nilai koefisien gempa horizontal. Simulasi apabila terkena gempa, koefisien gempa yang dimasukkan setengah dari nilai koefisien gempa sesungguhnya. Berikut hasil dari nilai koefisien gempa yang menjadi data masukan dalam analisis rencana tanggul Wedok (Tabel 4). 


\section{Kestabilan Tubuh Tanggul}

Tanpa perbaikan tanah dasar

Permodelan kestabilan tubuh tanggul tanpa sistem perbaikan tanah dasar dengan material timbunan dari borrow area dapat dilihat pada Gambar 7(a) dan untuk hasil kestabilan tubuh tanggul tanpa perbaikan tanah dengan material campuran antara borrow area 70\% dengan lumpur Sidoarjo 30\% dapat dilihat pada Gambar 7(b).

Rekayasa tanah dasar dengan pemasangan PVD Hasil analisis dari uji laboratorium diperoleh metode perbaikan tanah yang paling sesuai yaitu dengan pemasangan PVD sedalam 20 meter dengan jarak 1 meter seperti dimodelkan pada Gambar 8.

\section{Rekapitulasi Nilai SRF (Strength Reduction Factor). \\ SRF merupakan besaran di dalam shear reduction method, dimana nilai SRF diasumsikan sama dengan nilai FK (Santoso dkk, 2016). Hasil perhitungan SRF tubuh tanggul pada rencana tanggul Wedok secara keseluruhan dapat dilihat pada Tabel 5 .}

\section{PEMBAHASAN}

Kondisi Relief dan Lumpur Daerah Penelitian Kondisi daerah genangan lumpur memiliki relief yang lebih tinggi sedangkan wilayah pemukiman berada pada relief rendah. Pada bagian selatan wilayah pemukiman berupa cekungan. Kondisi relief seperti ini sangat berbahaya apabila tanggul utama mengalami kerusakan. Limpasan lumpur akan menuju ke daerah yang lebih rendah dan terakumulasi ke cekungan. Secara umum daerah penelitian sebagian besar didominasi keberadaan tipe lumpur air berlumpur yang memiliki kemampuan merusak tanggul paling tinggi.

Pengujian sondir memperlihatkan hasil yang cukup konsisten antara sondir satu dan sondir dua. Berdasarkan hubungan antara $\mathrm{qc}\left(\mathrm{kg} / \mathrm{cm}^{2}\right)$ dan rasio gesekkannya Fn (\%), lapisan tanah dasar di bawah urugan didominasi oleh lapisan lempung dan lanau berkonsistensi sangat lunak sampai dengan lunak hingga akhir penyelidikan sondir.

Pada titik sondir S-1 ditemukan sisipan lensa kepasiran sangat lepas dengan nilai $\mathrm{Qc}=11$ $\mathrm{kg} / \mathrm{cm}^{2}$ sampai $20 \mathrm{~kg} / \mathrm{cm}^{2}$, yang berada pada kedalaman $\pm 4,6 \mathrm{~m}$ sampai 7,2 $\mathrm{m}$. Pengujian pada titik sondir S-1 dan S-2 terhenti pada kedalaman $30 \mathrm{~m}$.
Hasil pengujian kadar air diperoleh nilai antara $70 \%$ hingga $151 \%$. Jenis tanah yang diperoleh yaitu silty clay, sedangkan klasifikasi tanah (cassagrande) yaitu $\mathrm{MH} \& \mathrm{OH}$ (lanau anorganik kompresibilitas tinggi dan lempung).

Tabel 4. Nilai koefisien gempa yang dimasukkan ke

\begin{tabular}{cccc}
\multicolumn{4}{c}{ dalam software Phase V8.0 } \\
\hline No & \multicolumn{1}{c}{ Periode } & $\mathrm{K}_{\mathrm{h}}$ & $\mathrm{K}_{\mathrm{v}}$ \\
& Ulang (T) & & \\
\hline 1. & $\begin{array}{c}1 / 250 \\
\text { (OBE) }\end{array}$ & 0,053 & 0,0265 \\
2. & $\begin{array}{c}\text { 1/25.000 } \\
\text { (MDE) }\end{array}$ & 0,161 & 0,0805 \\
& & \\
\hline
\end{tabular}

Tabel 5. Rekapitulasi Nilai SRF

\begin{tabular}{|c|c|c|c|}
\hline Material & $\begin{array}{l}\text { FK } \\
\text { Syarat }\end{array}$ & $\begin{array}{l}\text { Nilai } \\
\text { SRF }\end{array}$ & Keterangan \\
\hline \multicolumn{4}{|c|}{ 1. TANPA PERBAIKAN TANAH DASAR } \\
\hline \multicolumn{4}{|c|}{$\begin{array}{l}\text { Tanpa Beban } \\
\text { Gempa }\end{array}$} \\
\hline Borrow area & 1,3 & 0,68 & Tidak Aman \\
\hline Campuran & 1,3 & 0,67 & Tidak Aman \\
\hline \multicolumn{4}{|c|}{ 2. REKAYASA GEOTEKNIK (PVD) } \\
\hline \multicolumn{4}{|c|}{ A. KONDISI TANGGUL KOSONG } \\
\hline \multicolumn{4}{|c|}{ Tanpa Beban Gempa } \\
\hline Borrow area & 1,3 & 1,47 & Aman \\
\hline Campuran & 1,3 & 1,38 & Aman \\
\hline \multicolumn{4}{|c|}{ Dengan Beban Gempa OBE } \\
\hline Borrow area & 1,2 & 1,22 & Aman \\
\hline Campuran & 1,2 & 1,2 & Aman \\
\hline \multicolumn{4}{|c|}{ Dengan Beban Gempa MDE } \\
\hline Borrow area & 1,0 & 1,15 & Aman \\
\hline Campuran & 1,0 & 1,06 & Aman \\
\hline \multicolumn{4}{|c|}{ B. KONDISI TANGGUL BANJIR } \\
\hline \multicolumn{4}{|c|}{ Tanpa Beban Gempa } \\
\hline Borrow area & 1,3 & 1,55 & Aman \\
\hline Campuran & 1,3 & 1,43 & Aman \\
\hline \multicolumn{4}{|c|}{ Dengan Beban Gempa OBE } \\
\hline Borrow area & 1,2 & 1,46 & Aman \\
\hline Campuran & 1,2 & 1,25 & Aman \\
\hline \multicolumn{4}{|c|}{ Dengan Beban Gempa MDE } \\
\hline Borrow area & 1,0 & 1,27 & Aman \\
\hline Campuran & 1,0 & 1,1 & Aman \\
\hline \multicolumn{4}{|c|}{ C. KONDISI TANGGUL SURUT TIBA-TIBA } \\
\hline \multicolumn{4}{|c|}{ Tanpa Beban Gempa } \\
\hline Borrow area & 1,3 & 1,4 & Aman \\
\hline Campuran & 1,3 & 1,07 & Tidak Aman \\
\hline \multicolumn{4}{|c|}{ Dengan Beban Gempa OBE } \\
\hline Borrow area & 1,1 & 1,19 & Aman \\
\hline Campuran & 1,1 & 0,9 & Tidak Aman \\
\hline \multicolumn{4}{|c|}{ Dengan Beban Gempa MDE } \\
\hline Borrow area & 1,0 & 1,05 & Aman \\
\hline Campuran & 1,0 & 0,8 & Tidak Aman \\
\hline
\end{tabular}



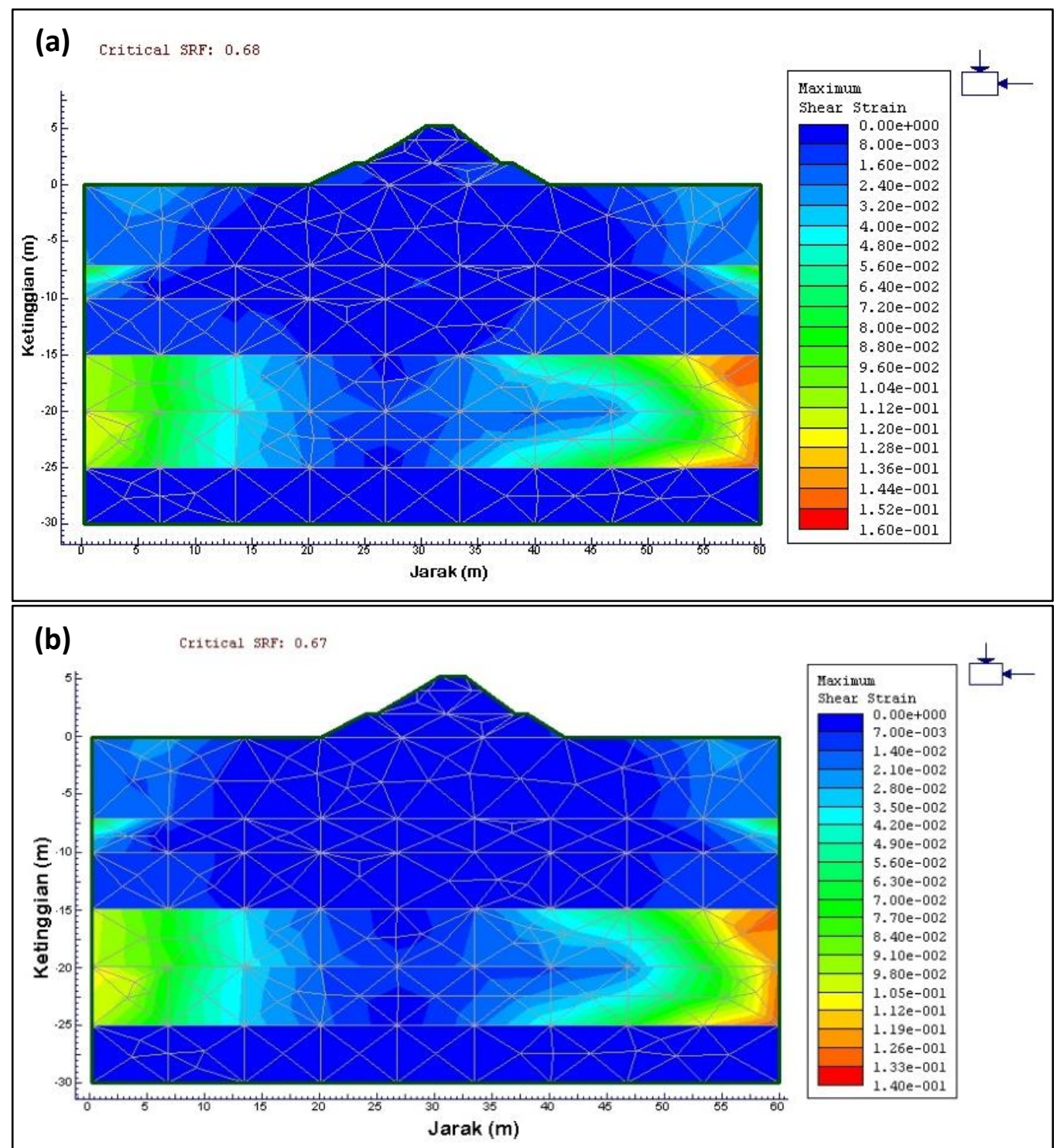

Gambar 7. Analisis kestabilan tubuh tanggul dengan material timbunan dari (a) borrow area dan (b) timbunan campuran.

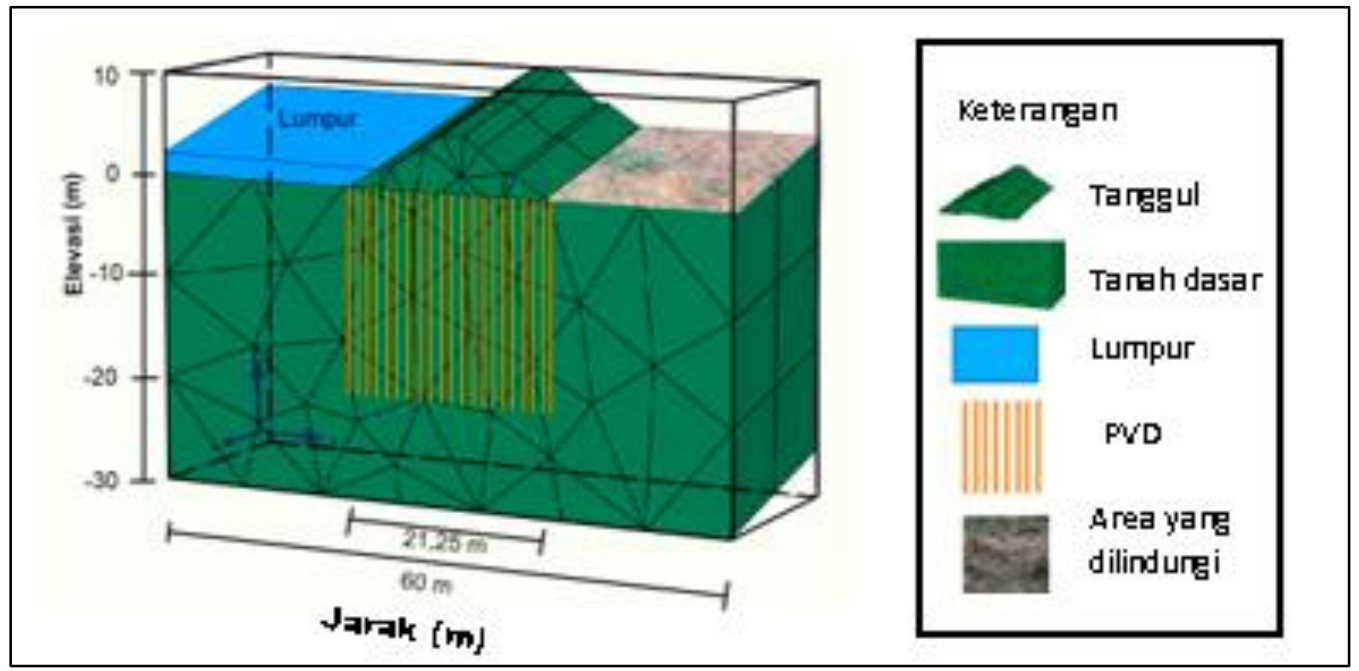

Gambar 8. Analisis kestabilan tubuh tanggul dengan material timbunan campuran. 
Berdasarkan hubungan potensi pengembangan dan PI (Chen, 1988), jenis tanah tersebut memiliki potensi mengembang tinggi. Kondisi tersebut Pengembangan yang tinggi jika dilakukan rekontruksi bangunan diatasnya dapat menyebabkan kegagalan tanggul.

\section{Hubungan Karakteristik Tanah Dasar dan Kestabilan Tubuh Tanggul}

Berdasarkan perhitungan daya dukung tanah yang telah dilakukan, tanah dasar hanya mampu menahan beban tanggul dengan dimensi tinggi 2,15 meter. Untuk mencapai daya dukung yang diinginkan (tinggi tanggul $5 \mathrm{~m}$ ) maka dilakukan perbaikan tanah. Perbaikan tanah dilakukan dengan metode geotextile jenis nonwoven dengan posisi vertikal atau lebih dikenal dengan Prefabricated Vertical Drain (PVD).

Perhitungan kestabilan tubuh tanggul yang dilakukan pada material dari borrow area maupun material campuran dari borrow area $70 \%$ dengan lumpur Sidoarjo 30\% yang diletakkan di atas tanah dasar tanpa adanya sistem perbaikan menunjukkan nilai tidak aman (Tabel 5), yakni 0,68 dan 0,67 . Nilai tersebut termasuk dalam nilai kritis.

Perhitungan dilakukan kembali pada tubuh tanggul dengan memasukkan simulasi sistem perbaikan tanah PVD. Parameter masukan pada program Phase V8.0 yaitu kekakuan normal dengan notasi EA sebesar $260 \mathrm{kN} / \mathrm{m}$. Panjang rencana pemasangan PVD sekitar $20 \mathrm{~m}$. Penentuan panjang PVD dari lapisan lempung lunak dengan jarak $1 \mathrm{~m}$. Penambahan beban material timbunan dilakukan secara bertahap untuk mencegah terjadinya kegagalan rekontruksi tanggul. Pemberian beban timbunan dilakukan secara bertahap dengan tujuan untuk meningkatkan kekuatan tanah lempung secara bertahap pula dan mengingat kondisi tanah dasar tidak memungkinkan untuk diberi beban timbunan sesuai ketinggian yang direncanakan. Pembebanan tahap awal setelah pemasangan PVD dimaksimalkan pada 2,15 $\mathrm{m}$ sesuai dengan hasil perhitungan daya dukung tanah.

Hasil perhitungan SRF pada tubuh tanggul baik menggunakan material borrow area maupun campuran menunjukkan bahwa ada peningkatan nilai. Dari kondisi kritis ke kondisi aman. Perhitungan SRF yang dilakukan pada 3 kondisi tanggul, yakni kosong, banjir dan surut tiba-tiba menghasilkan kondisi aman.
Berdasarkan rekapitulasi perhitungan SRF pada Tabel 5, perbaikan tanah dengan PVD efektif untuk meningkatkan faktor keamanan pada rencana tanggul Wedok. Material timbunan dari borrow area memiliki nilai SRF yang lebih tinggi dibandingkan dengan material timbunan dari campuran anatara borrow area $70 \%$ dengan lumpur Sidoarjo 30\%. Material timbunan dari borrow area memiliki nilai keamanan di atas persyaratan faktor keamanan tanggul tipe urugan pada berbagai kondisi sehingga material timbunan dari borrow area dapat digunakan pada pembangunan tanggul Wedok sedangkan material timbunan dari campuran antara borrow area $70 \%$ dengan lumpur Sidoarjo $30 \%$ memiliki nilai keamanan di atas persyaratan faktor keamanan tanggul tipe urugan pada kondisi tanggul kosong dan tanggul banjir. Namun pada kondisi tanggul surut tiba-tiba nilai keamanan berada di bawah FK syarat baik pada kondisi tanpa beban gempa, dengan beban gempa OBE maupun dengan beban gempa MDE sehingga material campuran ini tidak disarankan untuk pembangunan tanggul pada lumpur Sidoarjo.

\section{KESIMPULAN}

Pada lumpur Sidoarjo sebelah timur terdapat tipe air berlumpur yang memiliki potensi besar merusak tanggul utama. Berdasarkan hasil pemetaan geologi daerah penelitian diperoleh dua satuan litologi yaitu satuan endapan lumpur Sidoarjo dan satuan endapan aluvial. Berdasarkan hasil pemetaan geologi teknik diperoleh tiga satuan litologi yaitu satuan tanah urugan, satuan lumpur Sidoarjo, dan satuan tanah asli (lempung pasiran). Kekuatan tanah dasar tanpa perbaikan tanah pada daerah penelitian dapat menahan beban material timbunan setinggi 2,15 meter. Perbaikan tanah dasar dengan PVD efektif dilakukan karena dapat mempercepat proses konsolidasi dan meningkatkan kestabilan tanggul. Dari hasil analisis kestabilan pada rencana tanggul Wedok dengan software Phase2 V8.0 pada material dari borrow area aman dalam berbagai kondisi sedangkan dengan material campuran antara borrow area $70 \%$ dengan lumpur Sidoarjo 30\% tidak aman.

\section{UCAPAN TERIMA KASIH}

Penulis mengucapkan terima kasih kepada pihak Badan Penanggulangan Lumpur Sidoarjo yang telah berkenan memberikan 
kesempatan melakukan pengukuran data di lokasi.

\section{DAFTAR PUSTAKA}

Ambarini, E., Hirnawan, F., dan Guntoro, D., 2014. Sistem Stabilitas Lubang Bukaan Pengembangan dengan Menggunakan Rockbolt dan Sotcrete di Blok Cikoneng PT Cibaliung Sumberdaya Kabupaten Pandeglang, Provinsi Banten. Prosiding Teknik Pertambangan. 168-172.

Badan Penanggulangan Lumpur Sidoarjo, 2016. Data Semburan Lumpur Sidoarjo. Surabaya: Badan Penanggulangan Lumpur Sidoarjo.

Badan Standarisasi Nasional, 2004. Pedoman Konstruksi dan Bangunan : Instrumentasi Tubuh Bendungan Tipe Urugan dan Tanggul. Jakarta: Badan standarisasi Nasional.

Badan Standarisasi Nasional, 2016. Metode Analisis Stabilitas Lereng Bendungan Tipe Urugan. Jakarta: Badan Standarisasi Nasional.

Balai Litbang Sungai Surakarta, 2018. Laporan Rancangan Pembangunan tanggul Wedok Lumpur Sidoarjo. Surakarta: Balai Litbang Sungai Surakarta.

Chen, F. H., 1988. Foundation on Expansive Soil Development in Geotechnical Engineering. New York: Elsevier.

Mulyadi, S., 2011. Analisa Tegangan Regangan Produk Tongkat Lansia dengan Menggunakan Metode Elemen Hingga. Jurnal Rotor. (4)1.

Raden, W. M., Hamdan, I. M., Bemby, S., 2016. Pemodelan Vertical Drain dengan Menggunakan Model Elemen Hingga pada Analisis Konsolidasi di Bendungan Marangkayu Kalimantan Timur. Reka Racana. 2(3).

Santoso, Sari, E., Wibawa, A., dan Tobing, R., 2016. Analisis Kestabilan Lereng Menggunakan Kesetimbangan Batas dan Metode Elemen Hingga di Kecamatan wonolelo Sawangan, Kabupaten Magelang, Jawa Tengah. Jurnal Teknik UPN. 8(2).
Schmertmann, J. H., 1978. Guidelines for Cone Penetration Test, Performance and Design. Washington, DC: Departement of Transportation .

Sukandi, 2011. Analisis Kestabilan Tanggul Penahan Luapan Lumpur Berdasarkan Deformasi Tanah Bawah Permukaan Tanggul Menggunakan Metode Elemen Hingga dan Aplikasi Plaxis . Surabaya: Badan Penanggulangan Lumpur Sidoarjo.

Terzaghi, K., 1943. Theoretical Soil Mechanics. New York: Wiley. 